\title{
Effect of Hypoproteinemia on Electrolyte Measurement by Direct and Indirect Ion Selective Electrode Methods
}

\author{
Mukesh Gohel $^{1} \quad$ Jemil S. Makadia ${ }^{1}$ Chandan Chakrabarti ${ }^{1}$ \\ ${ }^{1}$ Department of Biochemistry, Smt NHL Municipal Medical College, \\ Ahmedabad, Gujarat, India \\ Address for correspondence Jemil S. Makadia, MD, Department \\ of Biochemistry, Smt NHL Municipal Medical College, Ahmedabad, \\ Gujarat, India (e-mail: jemil_sjm@yahoo.com).
}

J Lab Physicians 2021;13:144-147.

\begin{abstract}
Keywords

- ion selective electrode

- electrolytes

- sodium

- potassium

- hypoproteinemia

Objective The aim of this study was to see the effect of hypoproteinemia on electrolyte measurement by two different techniques, that is, direct ion selective electrode (ISE) and indirect ISE.

Material and Method It was an observational study in which 90 serum samples with normal protein content (Group-1) were subjected to sodium $\left(\mathrm{Na}^{+}\right)$and potassium $\left(\mathrm{K}^{+}\right)$ measurements by direct and indirect ISE methods. In the same way, 90 serum samples with total protein $<5 \mathrm{~g} / \mathrm{dL}$ (Group-2) were subjected to $\mathrm{Na}^{+}$and $\mathrm{K}^{+}$measurements by direct and indirect ISE methods.

Result In samples from Group-1 patients, average $\mathrm{Na}^{+}$was $138.1 \pm 4.764 \mathrm{mmol} / \mathrm{L}$ by direct ISE method and $139.3 \pm 3.887 \mathrm{mmol} / \mathrm{L}$ by indirect ISE method while average $\mathrm{K}^{+}$ was $4.41 \pm 0.644 \mathrm{mmol} / \mathrm{L}$ by direct ISE method and $4.40 \pm 0.592 \mathrm{mmol} / \mathrm{L}$ by indirect ISE method. There was no statistically significant difference in $\mathrm{Na}^{+}$and $\mathrm{K}^{+}$values measured by different methods. In samples from Group- 2 patients, measured value of $\mathrm{Na}^{+}$ by direct ISE and indirect ISE was $134.57 \pm 5.520 \mathrm{mmol} / \mathrm{L}$ and $138.64 \pm 5.401 \mathrm{mmol} / \mathrm{L}$, respectively. Difference between these two values was statistically significant with $p$-value of $<0.0001$, but direct ISE and indirect ISE measured values of $\mathrm{K}^{+}$was $4.146 \pm$ $0.9639 \mathrm{mmol} / \mathrm{L}$ and $4.186 \pm 0.8989$, respectively, with no significant difference.

Conclusion Direct and indirect ISE methods are not comparable and showing significantly different results for $\mathrm{Na}^{+}$in case of hypoproteinemia. So, it is recommended that setups like intensive care unit or emergency department, where electrolyte values have significant treatment outcome, should follow direct ISE method and should compare its previous result with the same method. Both the methods should not be used interchangeably.
\end{abstract}

\section{Introduction}

Electrolytes are of major physiological importance as various functions of the body depend on electrolytes' balance. The electrolytes' measurement in serum samples is one of the most commonly performed tasks and it is one of the most important parameters as well. Estimations of electrolytes, mainly sodium $\left(\mathrm{Na}^{+}\right)$and potassium $\left(\mathrm{K}^{+}\right)$, are performed in published online June 21, 2021
DOI https://doi.org/

$10.1055 / \mathrm{s}-0041-1730821$ ISSN 0974-2727
C 2021. The Indian Association of Laboratory Physicians.

This is an open access article published by Thieme under the terms of the Creative Commons Attribution-NonDerivative-NonCommercial-License, permitting copying and reproduction so long as the original work is given appropriate credit. Contents may not be used for commercial purposes, or adapted, remixed, transformed or built upon. (https://creativecommons.org/licenses/by-nc-nd/4.0/).

Thieme Medical and Scientific Publishers Pvt. Ltd. A-12, 2nd Floor, Sector 2, Noida-201301 UP, India 
the clinical biochemistry laboratory, but they are also more commonly estimated at point of care.

There are mainly two methods-direct ion selective electrode (ISE) and indirect ISE-of electrolytes' estimation that are commonly used in clinical biochemistry laboratory nowadays. These measure different quantities; however, their results are comparable in normal samples. One technique measures the electrolyte content in the plasma water, which is known as direct ISE, and the other technique measures electrolyte content in the volume of total plasma, which is known as indirect ISE. ${ }^{1}$ Total plasma contains water and solid components. Thereby, the distribution between water and solid phase is of importance as far as measurement of electrolyte is concerned, as the protein and lipid content may vary from the normal and will lead to difference in the measurement values from the two different techniques. Electrolytes present only in water content of plasma and body only respond to that, so measurement of electrolytes in plasma water is of main importance. The variation in the solid phase of plasma, that are proteins and lipids, from the normal situation will cause an error on the reported electrolyte results from the indirect ISE method. ${ }^{1}$

The results from the two different types of analyzer, which work on two different techniques, direct ISE and indirect ISE, are comparable for samples with a normal content of solid phase. Many preanalytical variables affect accuracy in electrolyte measurement. So, it is required that all preanalytical variations should be eliminated. Any sample with altered total lipids and total proteins may affect results and treatment, which may be life threatening. ${ }^{2}$ Many studies have advocated not to use direct ISE and indirect ISE alternatively. ${ }^{3-5}$ Treating physician should keep in mind that electrolyte value might be altered due to laboratory variables, and they should correlate it with patient's condition. ${ }^{6}$

Certain clinical conditions including hypoproteinemia affect the results of electrolytes' estimations, which makes results incomparable between the two methods. Due to these types of errors, laboratories get to receive repeat samples unnecessarily and many times when they are required to rerun the same sample there is a waste of man, machine, and time, which ultimately leads to increase in testing cost and undesired treatment result. This study is to see the effect of hypoproteinemia on electrolyte estimation and to develop policy to report error-free results and decrease laboratory wasteful work.

\section{Material and Method}

Study Subjects: The study was done in the Biochemistry departments of Smt NHL Municipal Medical College and Sardar Vallabhbhai Patel Institute of Medical Sciences \& Research, Ahmedabad, India. Institutional Review Board's clearance was obtained for the study. Overall, 90 serum samples with normal total protein and 90 patients' samples with hypoproteinemia $(<5 \mathrm{~g} / \mathrm{dL})$ were included.

Study Design: This was an observational study. Aim of the study was to see the effect of hypoproteinemia on electrolyte measurement by two different techniques, that is, direct ISE and indirect ISE. Thus, 90 patients with normal protein content (Group-1) in serum were subjected to sodium $\left(\mathrm{Na}^{+}\right)$and potassium $\left(\mathrm{K}^{+}\right)$measurements by direct ISE (AVL, Roche) and indirect ISE (Advia 1800, Siemens). Same way, 90 patients with serum total protein $<5 \mathrm{gm} / \mathrm{dL}$ (Group-2) were subjected to $\mathrm{Na}^{+}$and $\mathrm{K}^{+}$measurements by these two techniques.

Methods of Measurements: All patients were subjected to detailed history and serum estimation for total protein, lipid profile, and electrolyte $\left(\mathrm{Na}^{+}, \mathrm{K}^{+}\right)$estimations. All the patients with high total lipid content and those who were on intravenous infusion were excluded from the study group. Hemolyzed samples were excluded as it affects potassium level.

The blood sample in plain evacuated tube was allowed to clot at room temperature. It was then centrifuged at 3,000 rpm for 10 minutes to separate serum samples and then analysis of serum for total protein, lipid profile, $\mathrm{Na}^{+}$, and $\mathrm{K}^{+}$(indirect ISE) was done within 1 hour of collection. All tests were performed in fully automated clinical chemistry analyzer, Advia 1800 , Siemens. $\mathrm{Na}^{+}$and $\mathrm{K}^{+}$estimation was also done by direct ISE technique using AVL, Roche.

Statistical Evaluation: The data obtained were analyzed by using statistical tests, unpaired $t$-test, for comparison between groups, and $p$-value was calculated; a $p$-value of $<$ 0.05 was taken as significant using GraphPad InStat.

\section{Results}

In our study, all the serum samples that were received in clinical biochemistry laboratory for estimation of total protein, lipid profile, and electrolytes were considered as part of study, but patients with abnormal total lipids were excluded. Thus, 90 patients with normal total protein and normal total lipids were included in Group-1 and 90 patients with hypoproteinemia with normal total lipids were included in Group-2. All these samples were subjected to $\mathrm{Na}^{+}$and $\mathrm{K}^{+}$estimation by two different methods, direct ISE and indirect ISE. Derived values were subjected to unpaired $t$-test and $p$-value was derived.

In samples from Group-1 patients, average $\mathrm{Na}^{+}$was $138.1 \pm$ $4.764 \mathrm{mmol} / \mathrm{L}$ by direct ISE method and $139.3 \pm 3.887 \mathrm{mmol} / \mathrm{L}$ by indirect ISE method, and $p$-value was 0.0609 , which shows that there was no statistically significant difference between the measured values of the same sample but by different methods (-Table 1, - Fig. 1). Average $\mathrm{K}^{+}$was $4.41 \pm$ $0.644 \mathrm{mmol} / \mathrm{L}$ by direct ISE method and $4.40 \pm 0.592 \mathrm{mmol} / \mathrm{L}$ by indirect ISE method. Also, $p$-value was 0.9329 , which again shows that there was no statistically significant difference between measured values of $\mathrm{K}^{+}$of same sample but by different methods (- Table 2, - Fig. 2).

In samples from Group-2 patients, average measured values of $\mathrm{Na}^{+}$by direct ISE and indirect ISE were $134.57 \pm$ $5.520 \mathrm{mmol} / \mathrm{L}$ and $138.64 \pm 5.401 \mathrm{mmol} / \mathrm{L}$, respectively. Difference between these two values was statistically significant with a $p$-value of $<0.0001$ ( - Table 1, - Fig. 1). Similarly, direct ISE and indirect ISE measured values of $\mathrm{K}^{+}$were 4.146 $\pm 0.9639 \mathrm{mmol} / \mathrm{L}$ and $4.186 \pm 0.8989$, respectively, but the $p$-value was 0.7737 , which suggests no significant difference (-Table 2, - Fig. 2). 
Table 1 Serum sodium $(\mathrm{Na}+)$ in patients with normal total protein and hypoproteinemia

\begin{tabular}{|l|l|l|l|l|l|}
\hline Serum total protein & Method & $n$ & Mean \pm SD $(\mathrm{mmol} / \mathrm{L})$ & SE of mean & $\boldsymbol{p}$-Value \\
\hline $\begin{array}{l}\text { Normal } \\
\text { (Group-1) }\end{array}$ & Direct ISE & 90 & $138.1 \pm 4.764$ & 0.5021 & 0.0609 \\
\cline { 2 - 6 } & Indirect ISE & 90 & $139.3 \pm 3.887$ & 0.4097 & $<0.0001$ \\
\hline \multirow{2}{*}{$\begin{array}{l}\text { Hypoproteinemia } \\
\text { (Group-2) }\end{array}$} & Direct ISE & 90 & $134.57 \pm 5.520$ & 0.5819 & 0.5694 \\
\cline { 2 - 5 } & Indirect ISE & 90 & $138.64 \pm 5.401$ & \\
\hline
\end{tabular}

Abbreviations: ISE, ion selective electrode; SD, standard deviation; SE, standard error.

Table 2 Serum potassium $(\mathrm{K}+)$ in patients with normal total protein and hypoproteinemia

\begin{tabular}{|l|l|l|l|l|l|}
\hline Serum total protein & Method & $n$ & Mean \pm SD (mmol/L) & SE of mean & $p$-Value \\
\hline $\begin{array}{l}\text { Normal } \\
\text { (Group-1) }\end{array}$ & Direct ISE & 90 & $4.41 \pm 0.644$ & 0.0679 & 0.9329 \\
\cline { 2 - 5 } & Indirect ISE & 90 & $4.40 \pm 0.592$ & 0.0624 & 0.7737 \\
\hline $\begin{array}{l}\text { Hypoproteinemia } \\
\text { (Group-2) }\end{array}$ & Direct ISE & 90 & $4.146 \pm 0.9639$ & 0.1016 & 0.0947 \\
\cline { 2 - 5 } & Indirect ISE & 90 & $4.186 \pm 0.8989$ & & \\
\hline
\end{tabular}

Abbreviations: ISE, ion selective electrode; SD, standard deviation; SE, standard error.

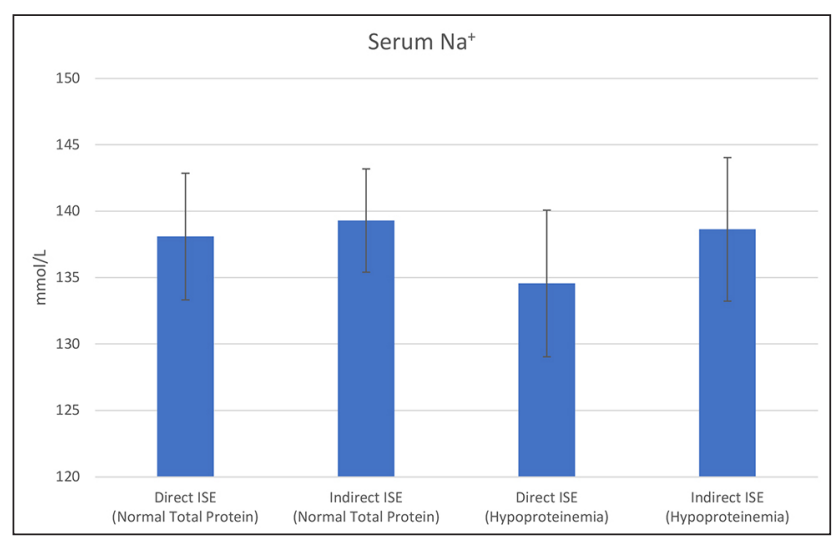

Fig. 1 Serum sodium $\left(\mathrm{Na}^{+}\right)$in patients with normal total protein and hypoproteinemia. ISE, ion selective electrode.

\section{Discussion}

Electrolyte estimation is very critical for the treatment of the patients, especially in intensive care units (ICUs) and emergency departments. Nowadays, more and more electrolytes' estimation is done at bedside, that is, point-of-care testing (POCT)-the estimation is usually based on direct ISE method. There are many small hospitals that do not have much patient load, so they usually send the samples to laboratories. If sample load in the laboratories is not high, then these small laboratories also perform electrolyte estimation on equipment that are usually based on direct ISE method, which is much reliable. But big hospitals that have their own laboratory and heavy sample load usually do electrolyte estimations on fully automated clinical chemistry analyzer, which is based on indirect ISE method. So, there is always a point of discussion whether results from indirect ISE are comparable with the results of direct ISE or not? There are many studies done on these to establish the effect of any preanalytical variables on the results. One such preanalytical parameter that might affect electrolyte estimation in indirect ISE method is total protein content.

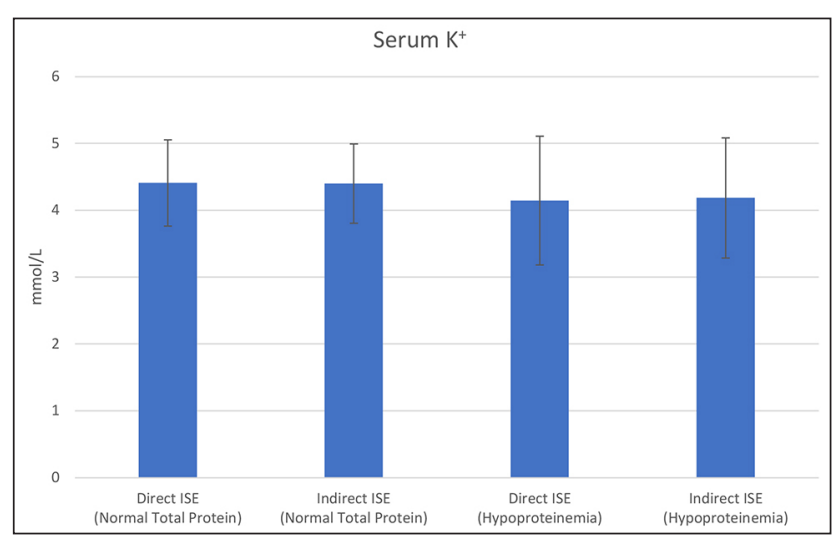

Fig. 2 Serum potassium $\left(\mathrm{K}^{+}\right)$in patients with normal total protein and hypoproteinemia. ISE, ion selective electrode.

In our study, we tried to see the effect of hypoproteinemia on electrolyte estimation comparing both the methods, direct ISE and indirect ISE. There are many studies that show that variation in total lipid affects the results of electrolytes, so we excluded the patients with abnormal lipid content in the serum. We measured $\mathrm{Na}^{+}$and $\mathrm{K}^{+}$by both the methods in patients with normal and low total protein in the serum. We observed that there was no significant difference between $\mathrm{Na}^{+}$and $\mathrm{K}^{+}$values in cases where total protein content in the serum was normal. But when samples of the patients with low total protein in the serum were analyzed for $\mathrm{Na}^{+}$and $\mathrm{K}^{+}$ by both the methods, it was observed that there was no significant difference between measured values of $\mathrm{K}^{+}$by both the methods, but measured values of $\mathrm{Na}^{+}$by both the methods showed significant difference with a $p$-value of $<0.0001$. Measured $\mathrm{Na}^{+}$values by direct ISE were low compared with indirect ISE in the patients with hypoproteinemia.

Various studies have been done to see the effect of total protein in the serum on electrolytes' estimation by both the methods. The differences in measured values of individual parameter may not be significant, but calculated parameters like anion gap may have statistically significant 
compounded difference. ${ }^{7}$ Madhavi and Nikhila recommend that POCT-based method and indirect ISE method should not be used interchangeably. ${ }^{3}$ Similarly, a study done by Jain et al to compare the results of POCT instrument and autoanalyzer found no significant difference between the measured values of potassium by both the instruments, though values measured by the POCT instrument and the autoanalyzer were significantly different for sodium. ${ }^{4}$ Clinicians and laboratory personnel should be aware of the preanalytical variables that affect the measured values of sodium by both the methods and should avoid using result interchangeably specially in emergency departments. ${ }^{5}$ Zelmet suggested not using indirect ISE method, specially in case where there is an alteration in protein content of the blood. ${ }^{8}$

Even though it is well known that total protein content may alter the outcome of the measured $\mathrm{Na}^{+}$value by indirect ISE method, no specific formula could be derived to correct the value as per protein content. ${ }^{9}$ There are studies that suggest ruling out any altered result of sodium by measuring protein and lipids in the serum. So pseudohyponatremia or pseudonormonatremia should be ruled out. ${ }^{10-12}$ So, there is an advantage with direct ISE method because results are unaffected by the presence of abnormal protein and lipid content, whereas indirect ISE results get affected. ${ }^{13,14}$ Chow et al showed that hypoproteinemia may lead to reporting of falsely high $\mathrm{Na}^{+}$values by indirect ISE method..$^{15}$

Though we found significant difference in measured $\mathrm{Na}^{+}$ values in case of hypoproteinemia between the two methods, it is also important that many other preanalytical variables also affect the results and hence total collective effect need to be assessed.

\section{Conclusion}

In our study, we observed that protein content does not alter measured $\mathrm{K}^{+}$values by direct and indirect ISE methods. Though direct ISE and indirect ISE are comparable while measuring $\mathrm{Na}^{+}$and $\mathrm{K}^{+}$in serum samples with normal protein and lipid content, both these methods are not comparable and showing significantly different results for $\mathrm{Na}^{+}$in case of hypoproteinemia. But we need to have large sample size to see the effect of altered values of total protein in blood on indirect ISE measured $\mathrm{Na}^{+}$value and to derive a specific formula. So, it is recommended that preanalytical variables like these should be considered before reporting $\mathrm{Na}^{+}$result, and especially in setups like ICU and emergency department where electrolyte values have significant effect on treatment outcome. These setups should follow direct ISE method or should compare its previous results with analyzing subsequent results by the same method. Both the methods should not be used interchangeably.

\section{Conflict of Interest}

None.

\section{References}

1 Holbek CC. Understanding the different values in electrolyte measurements. October 2002. Available at: https://acutecaretesting.org/en/articles/understanding-the-different-values-in-electrolyte-measurements. Accessed April 15, 2020

2 Ladenson JH, Apple FS, Aguanno JJ, Koch DD. Sodium measurements in multiple myeloma: two techniques compared. Clin Chem 1982;28(12):2383-2386

3 Madhavi, Nikhila G. Arterial blood gas analyser electrolytes versus serum electrolytes: a comparative study. Int J Life Sci Pharma Res 2018;8:37-51

4 Jain A, Subhan I, Joshi M. Comparison of the point-of-care blood gas analyzer versus the laboratory auto-analyzer for the measurement of electrolytes. Int J Emerg Med 2009;2(2):117-120

5 Datta SK. When direct and indirect ion selective electrode results conflict. AACC, Sept 1, 2018. Available at: https://www. aacc.org/publications/cln/articles/2018/september/when-direct-and-indirect-ion-selective-electrode-results-conflict. Accessed April 15, 2020

6 Liamis G, Liberopoulos E, Barkas F, Elisaf M. Spurious electrolyte disorders: a diagnostic challenge for clinicians. Am J Nephrol 2013;38(1):50-57

7 Igbokwe AA. Comparison of point of care testing (POCT) methods and central laboratory methods for key electrolytes. Newspath, CAP Point of Care Testing Committee. Available at: https://webapps.cap.org/apps/docs/newspath/0711/key_electrolytes.pdf. Accessed April 15, 2020

8 Zelmat MS. [Direct and indirect ion selective electrodes methods: the differences specified through a case of Waldenström's macroglobulinemia]. Ann Biol Clin (Paris) 2015;73(3):345-352

9 Jones BJ, Twomey PJ. Relationship of the absolute difference between direct and indirect ion selective electrode measurement of serum sodium and the total protein concentration. J Clin Pathol 2008;61(5):645-647

10 Fortgens P, Pillay TS. Pseudohyponatremia revisited: a modern-day pitfall. Arch Pathol Lab Med 2011;135(4):516-519

11 Dimeski G, Morgan TJ, Presneill JJ, Venkatesh B. Disagreement between ion selective electrode direct and indirect sodium measurements: estimation of the problem in a tertiary referral hospital. J Crit Care 2012;27(3):326.e9-326.e16

12 Callewaert N, Martens F, Muys M. Pseudohypernatremia at the intensive care unit: a cause for concern? Conference: BVKB-SBCC, At Brussels, October 2013. Available at: https://www.researchgate.net/publication/281405506_ Pseudohypernatremia_at_the_intensive_care_unit_a_cause for_concern. Accessed April 15, 2020

13 Higgins C. Spurious sodium results (1) - Pseudohyponatremia. March 2015. Available at: https://acutecaretesting.org/en/ articles/spurious-sodium-results-1-pseudohyponatremia. Accessed April 15, 2020

14 Higgins C. Spurious sodium results (2) - Pseudohyponatremia. June 2015. Available at: https://acutecaretesting.org/en/ articles/spurious-sodium-results2-pseudohypernatremia. Accessed April 15, 2020

15 Chow E, Fox N, Gama R. Effect of low serum total protein on sodium and potassium measurement by ion-selective electrodes in critically ill patients. $\mathrm{Br} \mathrm{J}$ Biomed Sci 2008;65(3):128-131 